\title{
Rootstock-regulated gene expression patterns associated with fire blight resistance in apple
}

\author{
Philip J Jensen ${ }^{1}$, Noemi Halbrendt ${ }^{1,2}$, Gennaro Fazio ${ }^{3}$, Izabela Makalowska ${ }^{4}$, Naomi Altman $^{5}$, Craig Praul ${ }^{6}$, \\ Siela N Maximova ${ }^{7}$, Henry K Ngugi ${ }^{1,2}$, Robert M Crassweller ${ }^{7}$, James W Travis ${ }^{1,2}$ and Timothy W McNellis ${ }^{1 *}$
}

\begin{abstract}
Background: Desirable apple varieties are clonally propagated by grafting vegetative scions onto rootstocks. Rootstocks influence many phenotypic traits of the scion, including resistance to pathogens such as Erwinia amylovora, which causes fire blight, the most serious bacterial disease of apple. The purpose of the present study was to quantify rootstock-mediated differences in scion fire blight susceptibility and to identify transcripts in the scion whose expression levels correlated with this response.

Results: Rootstock influence on scion fire blight resistance was quantified by inoculating three-year old, orchardgrown apple trees, consisting of 'Gala' scions grafted to a range of rootstocks, with E. amylovora. Disease severity was measured by the extent of shoot necrosis over time. 'Gala' scions grafted to G.30 or MM.111 rootstocks showed the lowest rates of necrosis, while 'Gala' on M.27 and B.9 showed the highest rates of necrosis. 'Gala' scions on M.7, S.4 or M.9F56 had intermediate necrosis rates. Using an apple DNA microarray representing 55,230 unique transcripts, gene expression patterns were compared in healthy, un-inoculated, greenhouse-grown 'Gala' scions on the same series of rootstocks. We identified 690 transcripts whose steady-state expression levels correlated with the degree of fire blight susceptibility of the scion/rootstock combinations. Transcripts known to be differentially expressed during E. amylovora infection were disproportionately represented among these transcripts. A second-generation apple microarray representing 26,000 transcripts was developed and was used to test these correlations in an orchard-grown population of trees segregating for fire blight resistance. Of the 690 transcripts originally identified using the first-generation array, 39 had expression levels that correlated with fire blight resistance in the breeding population.

Conclusions: Rootstocks had significant effects on the fire blight susceptibility of 'Gala' scions, and rootstockregulated gene expression patterns could be correlated with differences in susceptibility. The results suggest a relationship between rootstock-regulated fire blight susceptibility and sorbitol dehydrogenase, phenylpropanoid metabolism, protein processing in the endoplasmic reticulum, and endocytosis, among others. This study illustrates the utility of our rootstock-regulated gene expression data sets for candidate trait-associated gene data mining.
\end{abstract}

\section{Background}

Fire blight, the disease caused by the bacterial pathogen Erwinia amylovora (Burrill) [1], is a devastating, systemic disease that occurs in apples and other Rosaceous plants. Control is limited to pruning of infected branches and the use of antibiotics and copper compounds, both of which are only preventative, and are often strictly regulated. In addition, the emergence of streptomycin-resistant strains

\footnotetext{
* Correspondence: twm4@psu.edu

'Department of Plant Pathology, The Pennsylvania State University, University Park, PA 16802, USA

Full list of author information is available at the end of the article
}

of Erwinia amylovora has raised questions about the continued use of this control agent [2]. Once established, infection leads to the development of necrotic regions on the leaves, shoots and petals. The infected regions of the plant eventually become brown or black and look as if swept by fire [3]. Severe fire blight outbreaks can result in the destruction of whole orchards. Current production methods have shifted towards high-density plantings on dwarfing or very-dwarfing rootstocks, resulting in greater yields per acre [4]. However many of the dwarfing rootstocks are highly susceptible to fire blight, resulting in greater disease problems.

\section{Biomed Central}


The susceptibility of the different rootstocks and scion cultivars to fire blight varies substantially, and there are recommendations against certain combinations in regions particularly prone to fire blight [5]. It has been observed in the field and in the greenhouse that a given cultivar can have different levels of disease resistance depending on the rootstock to which it is grafted [6,7]. In the case of susceptible scion cultivars, it is recommended that they be grafted to resistant rootstocks to reduce susceptibility to fire blight. In the current study we demonstrate that rootstocks can have a significant effect on the resistance of the scion to fire blight.

A number of plant genes and pathways have been implicated as playing roles in the response to E. amylovora infection. Several pathogenesis related $(P R)$ genes have been shown to be up-regulated in apple in response to E. amylovora infection $[8,9]$. Overexpression of NPR1 in apple results in increased $P R$ gene expression and reduced susceptibility to $E$. amylovora and a number of other pathogens [10]. Norelli et al. [11] identified transcripts that are differentially expressed between control and E. amylovora-infected shoots using suppression subtractive cDNA hybridization. Recently, further studies identified additional transcripts that are differentially expressed during E. amylovora infection of apple leaves [12] and in apple flowers [13].

E. amylovora has been shown to specifically delay the expression of host genes in the phenylpropanoid pathway during infection $[14,15]$. This pathway leads to the production of anti-microbial compounds as well as lignin formation [16,17]. In addition, a general increase in free carbohydrate levels has also been associated with increased fire blight susceptibility [15].

Genetic analysis in apple is difficult due to its largely self-incompatible nature, high degree of heterozygosity, and large genome. However, the clonal propagation of apples provides an opportunity for genetic analysis of rootstock-regulated phenotypes, such as disease resistance. In a previous study, we used DNA microarrays to examine steady-state gene expression in the shoot tips of healthy, uninfected 'Gala' apple scions grafted to seven different rootstocks [18]. Each of the scion/rootstock combinations had a unique phenotype. In the present study, we undertook to identify constitutively expressed genes in 'Gala' apple whose expression levels were associated with a rootstock-induced decrease in fire blight susceptibility. Using fire blight resistance ratings from field-grown trees, we were able to mine the microarray data obtained during the earlier study [18] to identify genes and pathways that might be related to the tree fire blight susceptibility status. Previously, we used a similar approach to identify transcripts whose expression levels correlated with tree stature [18].

\section{Methods}

\section{Plant Material}

Trees for the fire blight tests were purchased from Adams County Nursery Inc. (Aspers, PA) and planted in five replica blocks at The Pennsylvania State University Fruit Research and Extension Center, Biglerville, PA. Trees consisting of 'Gala' scions grafted to a range of rootstocks were planted and conventionally managed with pesticides to control weeds, fungal diseases and insects in preparation for inoculation. For the greenhouse-grown tree firstgeneration microarrays, fresh bench grafts were grown as described previously [18]. For fire blight susceptibility tests, 'Crimson Gala' (Waliser cultivar) on the same seven rootstocks were planted in 2005 at the Fruit Research and Extension Center in Biglerville, PA. The rootstocks were, from the least to the most vigorous, Malling 27 EMLA (M.27), Budagovsky 9 (B.9), Malling 9 Fleuren 56 (M.9F56), Geneva 30 (G.30), Malling 7 EMLA (M.7), Supporter 4 (S.4), Malling Merton 111 EMLA (MM.111). Throughout the text, plants are described as scion/rootstock combinations. For example, a 'Gala' scion on an M.7 rootstock is designated as 'Gala'/M.7. The trees used for the second-generation microarray experiment were from a segregating population from an 'Ottawa 3' × 'Robusta 5' cross and were grown in an orchard in Geneva, NY [19]. This population had been previously characterized for resistance to fire blight [19].

\section{Fire Blight Susceptibility}

For the fire blight tests conducted in Biglerville, PA, actively growing scion shoot tips of three-year old trees were wounded by using scissors to cut across the midribs of the youngest leaves, and a drop of phosphate buffer (10 $\mathrm{mM}, \mathrm{pH} 7$ ) containing $1 \times 10^{6} \mathrm{cfu} / \mathrm{ml}$ of $E$. amylovora (strain Ea581a or HKN06P1) was placed on the cut surface. The shoot tip was then covered for 24 hours with a plastic bag containing a wet piece of filter paper to maintain a humid environment and promote infection. Necrotic region measurements were taken over the course of the disease progression. Disease severity was calculated as the length of the blighted section of an inoculated shoot as a percentage of the total shoot length. Four replicate trials were conducted, each replicate consisting of 10 trees of each of the 7 scion/rootstock combinations. At least 5 shoots per tree were inoculated. The fire blight susceptibility of the 'Ottawa 3' $\times$ 'Robusta 5' cross progeny used for the second-generation microarray experiment, to two $E$. amylovora strains (Ea273, Ea2002a), was published previously [19]. The susceptibility data for a third E. amylovora strain (Ea4001a) is unpublished.

\section{RNA isolation and microarray analysis}

The methods and results for our first-generation microarray, including RNA isolations from greenhouse-grown 
trees and microarray analysis, are described elsewhere [18]. The first generation array contained probes designed to detect 55,230 unique transcripts, representing up to $95 \%$ coverage of the apple genome. The sequences for all of the contigs used to develop the probes for the arrays can be found at the Gene Expression Omnibus (GEO) dataset website [20]. For the present study, we developed and used a second-generation apple DNA NimbleGen expression microarray that was designed based on our first-generation NimbleGen array [18] and used it to analyze RNA samples isolated from the progeny of the 'Ottawa 3' $\times$ 'Robusta 5' cross grown in Geneva, NY. The expression levels for each tree were analyzed on a single array only, with no biological replicates for any individual tree. The second-generation array was a 12-plex array containing 135,000 probes per plex, representing 26,017 transcripts, enabling us to query a relatively large number of samples. The probes for this array represent a subset of those included in the first-generation array. The second-generation array represents the transcripts with the best-performing probe sets from the first-generation array and includes the transcripts that showed differential expression between any two scion/rootstock combinations. Transcripts that had high variability among their probes were left off of the second-generation array. The five bestperforming probes of the original six probes per transcript were used in the second-generation array to increase the number of different transcripts that could be queried by the second-generation array.

DNA microarray analysis on our second-generation microarrays was performed by the Penn State Genomics Core Facility at University Park, PA. Briefly, one microgram of total RNA from each sample was amplified using the Ambion (Life Technologies) Amino Allyl MessageAmp II aRNA Amplification Kit (AM1753) following the manufacturer's protocol for one cycle amplification. Fifteen micrograms of aRNA was dye coupled with either Cy3 or Cy5 (GE Health Care \#RPN5661), as appropriate. Following quenching and cleanup of dye coupling reactions, $1.5 \mu \mathrm{g}$ of a Cy3 labeled sample is combined with 1.5 $\mu \mathrm{g}$ of a Cy5 labeled sample and fragmented using RNA Fragmentation Reagents (Ambion AM8740) according the manufacturer's instructions. After fragmentation, samples are dried down completely in a speed-vac and then resuspended in tracking controls and hybridization solution according to the microarray manufacturer's instructions (Roche NimbleGen). Pairs of samples were hybridized overnight at $42^{\circ} \mathrm{C}$ with active mixing in a MAUI Hybridization System. Following hybridization, microarrays were washed and scanned according to the manufacturer's protocol (Roche NimbleGen). Images were burst, gridded, and pair files generated using NimbleScan software. The gene expression data from the hybridization experiments using the second-generation DNA microarray were normalized using $\mathrm{R}$ software and un-adjusted $\mathrm{p}$-values were calculated by regression analysis using $\mathrm{R}$ software $[21,22]$.

\section{Multiple regression analysis}

Stepwise multiple regression analysis was used to identify genes whose expression levels were related to fire blight severity. The response variable was mean fire blight severity, calculated as the length of blighted section of an inoculated shoot as a percentage of the entire shoot and averaged across 5 replicates for each of 48 (Geneva trees). The explanatory variables were gene expression levels, expressed as arbitrary units of fluorescence intensity, for a set of 60 candidate genes selected based on potential for involvement in fire blight susceptibility. A full stepwise regression model was implemented so that each of the explanatory variables was evaluated in the regression with significance level for staying in the model set at $P=0.15$. For both up-regulated and down-regulated candidate genes, separate stepwise regression analyses were computed for fire blight severity data for each of three E. amylovora strains. Stepwise multiple regression analysis were implemented using the REG procedure of SAS 9.2 (SAS Institute Inc., Cary, NC), and the resulting models were evaluated for goodness of fit based on standard regression analysis procedures [23].

\section{Results}

Rootstock-dependent differences in fire blight susceptibility of 'Gala' scions

Significant differences in the relative size of the necrotic regions were observed within 15 days of inoculation of the 'Gala' shoot tips with two different strains of E. amylovora (Figure 1). For both strains, 'Gala'/G.30 and 'Gala'/M.111 were the least susceptible and 'Gala'/B.9 and 'Gala'/M.27 were the most susceptible. Interestingly, strain-dependent differences in fire blight susceptibility were observed for 'Gala'/M.7 and 'Gala'/M.9F56 trees. 'Gala'/M.7 susceptibility to $E$. amylovora strain Ea581a was similar to that of the most susceptible trees ('Gala'/B.9 and 'Gala'/M.27), while 'Gala'/M.9F56 susceptibility to strain Ea581a was similar to that of the most resistant trees ('Gala'/G.30 and 'Gala'/ MM.111). The results were reversed with $E$. amylovora strain HKN06P1, with 'Gala'/M.7 susceptibility being similar to that of the most resistant trees and 'Gala'/M.9F56 susceptibility being similar to that of the most susceptible trees. E. amylovora strain Ea581a is a moderately virulent isolate, while HKN06P1 is a hypervirulent isolate [24].

\section{Clustering of trees according to phenylpropanoid pathway gene expression}

After obtaining fire blight susceptibility ratings for all the 'Gala'/rootstock combinations used in the study, it became possible to ask whether expression levels of 


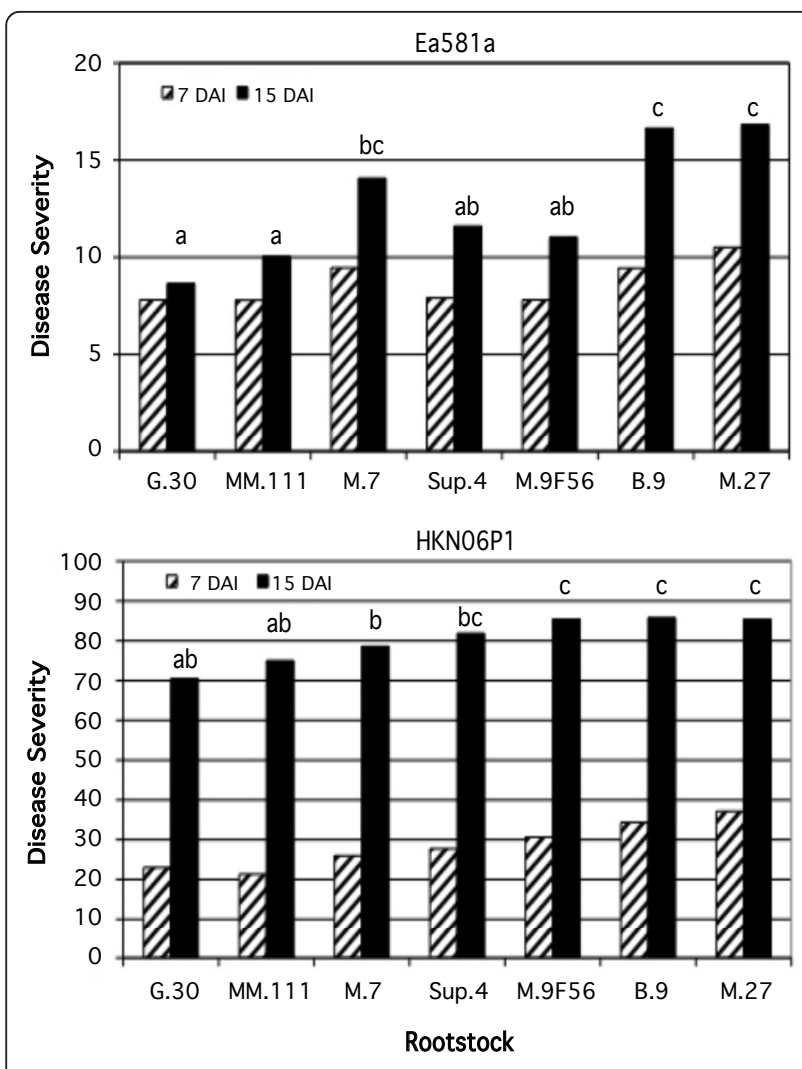

Figure 1 Susceptibility of grafted 'Gala' scions on seven different rootstocks to two different strains of $E$. amylovora. Bars sharing the same letter are not significantly different (Fisher's LSD).

genes involved in specific biochemical pathways related to fire blight resistance might contribute to the rootstock-regulated fire blight resistance phenotype. Gene expression levels in scions of all the 'Gala'/rootstock combinations used in this study were previously profiled on a large scale using our first-generation DNA microarray [18], and these microarray data were mined in the present study for genes related to fire blight susceptibility. Because the phenylpropanoid biosynthesis pathway has been implicated in fire blight resistance [11,14], a search of the apple genome was conducted to find the predicted phenylpropanoid biosynthetic pathway genes. A total of 67 transcripts on our first-generation array were identified as belonging to the phenylpropanoid biosynthetic pathway, among other pathways (Additional File 1, Table S1).

A complete linkage cluster analysis using the expression values for these genes was conducted to evaluate the potential contribution of the expression levels of genes in this pathway to resistance (Figure 2). There were two main clusters of trees based on the expression patterns of putative phenylpropanoid biosynthetic genes. The two least susceptible scion/rootstock combinations ('Gala'/

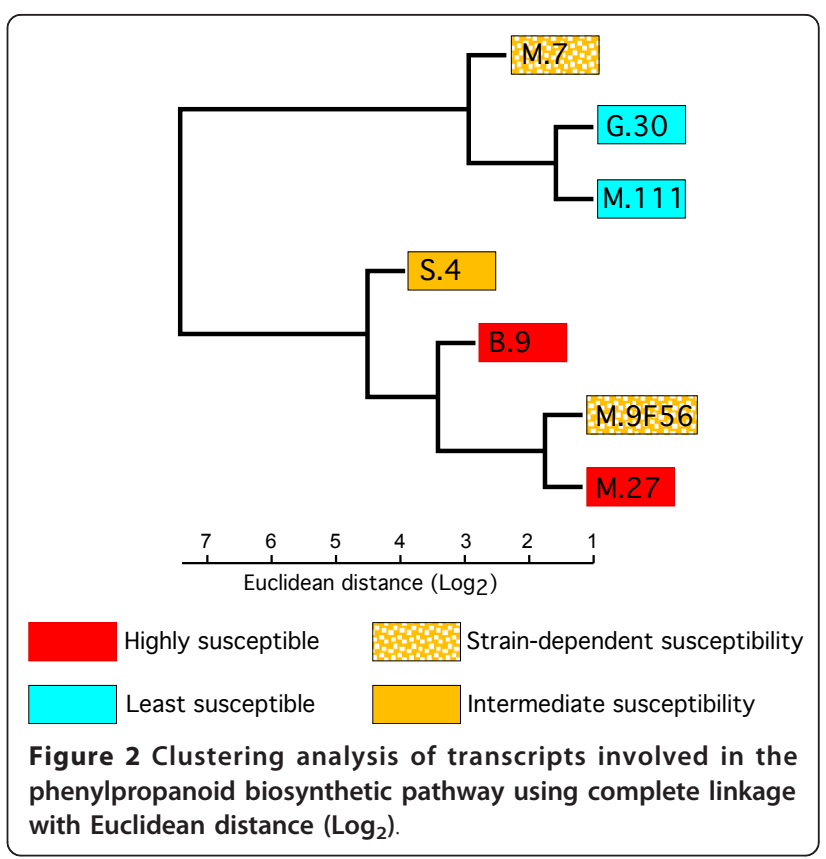

G.30 and 'Gala'/M.111) were paired in one cluster, along with a branch containing one scion/rootstock combination displaying strain-dependent susceptibility ('Gala'/ M.7). The second main cluster contained both of the highly susceptible scion/rootstock combinations ('Gala') M.27 and 'Gala'/B.9) as well as a scion/rootstock combination with strain-dependent susceptibility ('Gala'/ M.9F56) and the moderately susceptible scion/rootstock combination ('Gala'/S.4). Thus, the clustering of trees according to phenylpropanoid pathway gene expression closely followed the pattern of susceptibility to the highly virulent E. amylovora strain HKN06P1 (Figure 1).

\section{Clustering of trees according to sugar metabolic pathway gene expression}

The AraCyc metabolic pathways tool [25] was used to identify 93 Arabidopsis genes involved in sugar metabolism, and the potential homologs of these Arabidopsis genes in the apple genome were identified. A BLAST search of the set of the Arabidopsis genes involved in sugar metabolism to the apple genome resulted in the identification of 227 unique apple coding sequences. A total of 219 of these transcripts were represented on our first-generation array. A complete linkage cluster analysis using the expression values for the 219 identified sugar metabolism genes did not closely follow the pattern for the levels of fire-blight susceptibility for the various scion/rootstock combinations (compare Figures 1 \& $3)$. Instead, the clustering by sugar metabolism gene expression closely resembled clustering based on data for all the transcripts represented on the first-generation array [18]. 


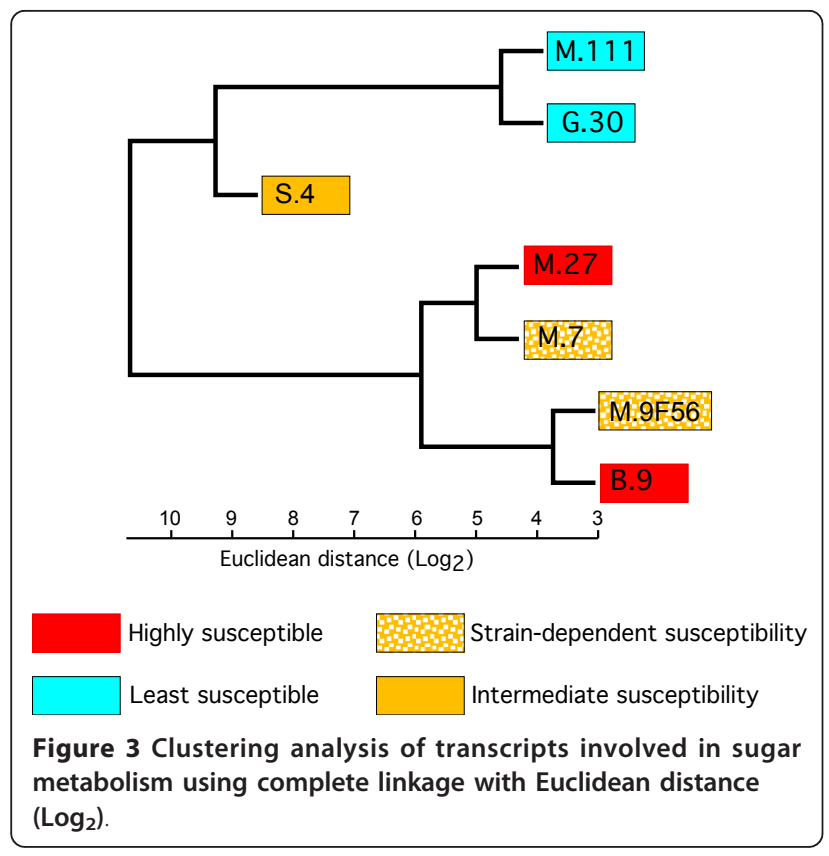

Identification and categorization of candidate rootstockregulated, fire blight susceptibility-associated transcripts Constitutive gene expression levels in scions of all the 'Gala'/rootstock combinations used in this study were profiled on a large scale previously using our first-generation apple DNA microarray [18]. Using the fire blight susceptibility ratings from the field trials, the microarray data were sorted to identify those transcripts whose expression levels correlated with the differences in fire blight susceptibility among the apple trees being studied. A diagram showing the comparisons used to sort the data is shown in Figure 4. Transcripts of interest were selected based on a fold-expression difference cutoff and a statistical strength cutoff. For a transcript to be selected, every possible pairwise comparison between the two least susceptible ('Gala'/G.30 and 'Gala'/M.111) and the two most susceptible scion/rootstock combinations ('Gala'/B.9 and 'Gala'/M/27) had to have at least a 1.5 fold difference in expression and a q-value of less than 0.05 . This selection program resulted in a list of 665 transcripts with higher expression levels in the less susceptible trees (Additional File 1, Table S2), and 25 transcripts with higher expression in the more susceptible trees (Additional File 1, Table S3) for a total of 690 candidate rootstock-regulated, fire blight susceptibility-associated transcripts. The Malus genome BLAST hits and corresponding e-values are included in Additional File 1, Tables S2 and S3.

An analysis of the predicted functional categories of all of the candidate rootstock-regulated, fire blight susceptibility-associated transcripts was conducted based on the Arabidopsis thaliana BLASTX hits to the Malus

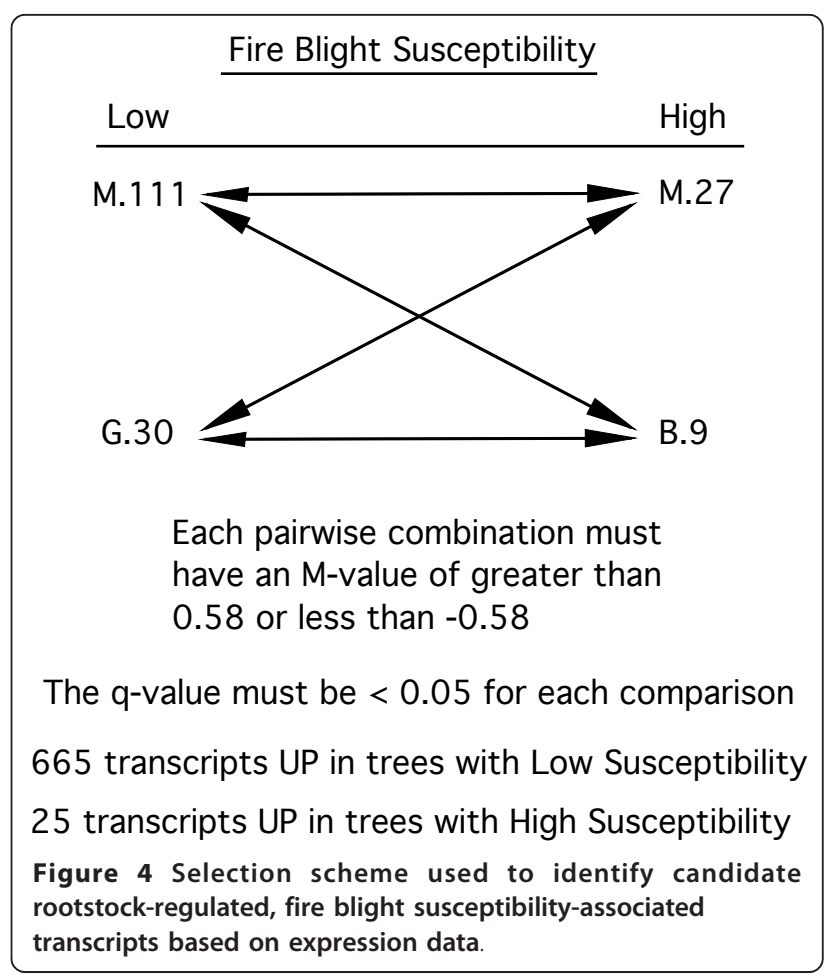

$\mathrm{x}$ domestica sequence (BLASTX cutoff 1E-3). The distribution in the functional categories differed from that expected based on the whole transcriptome. These Gene Ontology (GO) enrichment patterns are shown in Table 1. Transcripts of genes predicted to be involved in responses to stress and biotic and abiotic stimuli were disproportionately represented relative to the known apple transcriptome as a whole.

A functional annotation of the transcripts in Additional File 1, Table S2 was conducted using the Kyoto Encyclopedia of Genes and Genomes (KEGG) [26] to look for pathways that might be overrepresented among the candidate rootstock-regulated, fire blight susceptibility-associated transcripts. The sequence of every transcript on the array was subjected to KEGG analysis to generate an overall picture of the relative abundance of genes in the KEGG pathways. Similarly, all of the transcripts in Additional File 1, Tables S2 and S3 were analyzed for the KEGG pathways. A chi-square analysis revealed that, for the candidate rootstock-regulated, fire blight susceptibility-associated transcripts, several pathways contained more genes than predicted relative to a KEGG analysis of all of the transcripts represented on the array (Table 2). Those pathways that had the highest confidence level for being over-represented include: fatty acid metabolism (ko00071), valine, leucine and isoleucine degradation (ko00280), photosynthesisantenna proteins (ko00196), flavonoid biosynthesis (ko00941), protein processing in the endoplasmic reticulum (ko04141), endocytosis (ko4144) and peroxisome (ko4146). 
Table 1 GO Enrichment Analysis

\begin{tabular}{|c|c|c|c|}
\hline Keyword Category & Functional Category & Expected & Observed \\
\hline Biological Process & cell organization and biogenesis & 29 & 29 \\
\hline Biological Process & developmental processes & 22 & 21 \\
\hline Biological Process & DNA or RNA metabolism & 8 & 2 \\
\hline Biological Process & electron transport or energy pathways & 13 & 21 \\
\hline Biological Process & other biological processes & 20 & $37^{*}$ \\
\hline Biological Process & other cellular processes & 138 & 164 \\
\hline Biological Process & other metabolic processes & 146 & 162 \\
\hline Biological Process & protein metabolism & 60 & 60 \\
\hline Biological Process & response to abiotic or biotic stimulus & 23 & $53^{*}$ \\
\hline Biological Process & response to stress & 19 & $46^{*}$ \\
\hline Biological Process & signal transduction & 15 & 7 \\
\hline Biological Process & transcription & 23 & $4^{*}$ \\
\hline Biological Process & transport & 31 & 31 \\
\hline \multirow[t]{2}{*}{ Biological Process } & unknown biological processes & 124 & $33 *$ \\
\hline & & 670 & 670 \\
\hline
\end{tabular}

${ }^{*}$ Chi Square $<0.001$

Genes differentially expressed during fire blight infection are disproportionately represented among the candidate rootstock-regulated, fire blight susceptibility-associated transcripts

Transcripts that increase or decrease in abundance during fire blight infection have been identified in apple [11-13]. Of the 690 candidate, rootstock-regulated, fire blight susceptibility-associated transcript sequences identified in the present study (Additional File 1, Tables S2 \& S3), 79 (Table 3) had been determined to be differentially expressed during fire blight infection by Norelli et al., [11]. Based on BLAST searches of both sets of transcripts to the recently published apple genome [27], a number of the transcript sequences were found to represent different locations on the same predicted gene, resulting in a final set of 54 unique genes (Table 3). Based on the sizes of the candidate gene lists and the number of genes on the array and in the genome, approximately four genes are expected to be in common between the two data sets due to chance.

Similarly, a total of 20 of our candidates corresponded to 10 genes identified by Baldo et al., [12] (Table 4), out of a total of 190 genes identified in that study. Half of these 20 candidates were also among those identified by Norelli et al [11]. We also compared our candidate list to a list of $\sim 3,500$ genes identified as being differentially expressed during flower infection by Sarowar et al., [13] and found that 117 of our candidates shared an Arabidopsis BLAST hit (Additional File 1, Table S4). For Baldo et al., and Sarowar et al., the number of genes expected to be in common between the two data sets due to chance are 2 and 60 respectively.

Interestingly, of the 54 transcripts identified in common with Norelli et al., over half were down-regulated post infection [11]. However, we found that these same genes had higher expression levels in the less susceptible trees. A few of these were initially up-regulated in the Norelli study at early time points, but were down-regulated at later time points. In Sarowar et al., again over half of the transcripts in common were identified as being down-regulated upon infection; they were expressed at higher levels in the least susceptible trees in the present study. Only 2 of 10 of the genes in common with Baldo et al. were down-regulated upon infection. A KEGG analysis of the genes in Table 3 is included in Table 2. Those pathways that had the highest confidence level for being overrepresented relative to the total transcriptome include protein processing in the endoplasmic reticulum (ko04141) and endocytosis (ko4144).

\section{Analysis of expression patterns of candidate fire blight susceptibility-associated genes in an apple rootstock breeding population}

To further analyze which candidate rootstock-regulated, fire blight susceptibility-associated transcripts might prove to be the best indicators of resistance, we examined the expression levels of a subset of the candidate transcripts in a test population of 48 individual, non-grafted apple lines, grown in Geneva, NY, that were offspring from a single 'Ottawa 3' × 'Robusta 5' cross segregating for fire blight resistance. Expression was measured using a second-generation, 135,000 feature microarray (representing $\sim 26,000$ transcripts) developed from the original, larger microarray used for rootstock-regulated gene expression profiling [18]. The second-generation microarray was designed before the 690 fire blight-associated candidate transcripts had been identified; of the 690 
Table 2 KEGG functional analysis of candidate rootstock-regulated, fire blight susceptibility-associated transcripts

\begin{tabular}{|c|c|c|c|c|c|c|c|c|c|c|c|}
\hline \multirow[b]{2}{*}{ Pathway } & \multirow[b]{2}{*}{ KEGG no. } & \multirow{2}{*}{$\begin{array}{c}\text { Whole array } \\
\text { Total }\end{array}$} & \multicolumn{2}{|c|}{$\begin{array}{c}\text { Suppl } \\
\text { Table } 2\end{array}$} & \multicolumn{2}{|c|}{$\begin{array}{c}\text { Table } 3 \\
\text { transcripts }\end{array}$} & \multicolumn{2}{|c|}{$\begin{array}{c}\text { Table } 5 \\
\text { transcripts }\end{array}$} & \multicolumn{3}{|c|}{ p-value $>$} \\
\hline & & & Exp & Obs & Exp & Obs & Exp & Obs & Suppl Table 2 & Table 3 & Table 5 \\
\hline Fatty acid metabolism & 71 & 10 & 0.1 & 4 & $\mathrm{n} / \mathrm{a}$ & $\mathrm{n} / \mathrm{a}$ & $\mathrm{n} / \mathrm{a}$ & $\mathrm{n} / \mathrm{a}$ & 0.001 & $\mathrm{n} / \mathrm{a}$ & $\mathrm{n} / \mathrm{a}$ \\
\hline Protein processing in endoplasmic reticulum & 4141 & 60 & 0.8 & 8 & 0.3 & 3 & 0.3 & 3 & 0.001 & 0.001 & 0.001 \\
\hline Carbon fixation pathways in prokaryotes & 720 & 10 & 0.1 & 3 & $\mathrm{n} / \mathrm{a}$ & $\mathrm{n} / \mathrm{a}$ & $\mathrm{n} / \mathrm{a}$ & $\mathrm{n} / \mathrm{a}$ & 0.001 & $\mathrm{n} / \mathrm{a}$ & $\mathrm{n} / \mathrm{a}$ \\
\hline Peroxisome & 4146 & 30 & 0.4 & 5 & 0.2 & 1 & $n / a$ & $\mathrm{n} / \mathrm{a}$ & 0.001 & 0.05 & $\mathrm{n} / \mathrm{a}$ \\
\hline Photosynthesis-antenna proteins & 196 & 12 & 1.5 & 7 & 0.7 & 1 & 0.7 & 2 & 0.001 & NS & 0.001 \\
\hline Endocytosis & 4144 & 30 & 0.4 & 3 & 0.2 & 2 & 0.2 & 1 & 0.001 & 0.001 & 0.05 \\
\hline Valine, leucine and isoleucine degradation & 280 & 20 & 0.3 & 2 & $\mathrm{n} / \mathrm{a}$ & $\mathrm{n} / \mathrm{a}$ & $\mathrm{n} / \mathrm{a}$ & $\mathrm{n} / \mathrm{a}$ & 0.001 & $\mathrm{n} / \mathrm{a}$ & $\mathrm{n} / \mathrm{a}$ \\
\hline Carbon fixation in photosynthetic organisms & 710 & 22 & 2.8 & 8 & 1.3 & 2 & $\mathrm{n} / \mathrm{a}$ & $\mathrm{n} / \mathrm{a}$ & 0.01 & NS & $\mathrm{n} / \mathrm{a}$ \\
\hline Methane metabolism & 680 & 19 & 2.4 & 7 & 1.1 & 2 & $\mathrm{n} / \mathrm{a}$ & $\mathrm{n} / \mathrm{a}$ & 0.01 & NS & $\mathrm{n} / \mathrm{a}$ \\
\hline Spliceosome & 3040 & 95 & 12.2 & 3 & 5.5 & 1 & 5.2 & 1 & 0.01 & NS & NS \\
\hline Arginine and proline metabolism & 330 & 30 & 0.4 & 2 & $\mathrm{n} / \mathrm{a}$ & $n / a$ & $n / a$ & $n / a$ & 0.01 & $n / a$ & $n / a$ \\
\hline Flavonoid biosynthesis & 941 & 13 & 1.7 & 5 & & & 0.7 & 2 & 0.01 & & NS \\
\hline Antigen processing and presentation & 4612 & 6 & 0.8 & 3 & 0.3 & 2 & 0.3 & 2 & 0.05 & 0.01 & 0.01 \\
\hline Purine metabolism & 230 & 75 & 9.6 & 2 & $\mathrm{n} / \mathrm{a}$ & $\mathrm{n} / \mathrm{a}$ & $\mathrm{n} / \mathrm{a}$ & $\mathrm{n} / \mathrm{a}$ & 0.05 & $\mathrm{n} / \mathrm{a}$ & $\mathrm{n} / \mathrm{a}$ \\
\hline Pentose and glucuronate interconversions & 40 & 10 & 0.1 & 1 & n/a & n/a & n/a & $\mathrm{n} / \mathrm{a}$ & 0.05 & $n / a$ & $\mathrm{n} / \mathrm{a}$ \\
\hline Indole alkaloid biosynthesis & 901 & 1 & 0.1 & 1 & $\mathrm{n} / \mathrm{a}$ & $\mathrm{n} / \mathrm{a}$ & n/a & $\mathrm{n} / \mathrm{a}$ & 0.05 & $\mathrm{n} / \mathrm{a}$ & $\mathrm{n} / \mathrm{a}$ \\
\hline Neuroactive ligand-receptor interaction & 4080 & 1 & 0.1 & 1 & $\mathrm{n} / \mathrm{a}$ & $n / a$ & $\mathrm{n} / \mathrm{a}$ & $\mathrm{n} / \mathrm{a}$ & 0.05 & $\mathrm{n} / \mathrm{a}$ & $\mathrm{n} / \mathrm{a}$ \\
\hline Renin-angiotensin system & 4614 & 1 & 0.1 & 1 & $\mathrm{n} / \mathrm{a}$ & $\mathrm{n} / \mathrm{a}$ & $\mathrm{n} / \mathrm{a}$ & $\mathrm{n} / \mathrm{a}$ & 0.05 & $\mathrm{n} / \mathrm{a}$ & $\mathrm{n} / \mathrm{a}$ \\
\hline Benzoate degradation & 362 & 4 & 0.5 & 2 & $\mathrm{n} / \mathrm{a}$ & $\mathrm{n} / \mathrm{a}$ & 0.3 & 1 & 0.05 & $\mathrm{n} / \mathrm{a}$ & NS \\
\hline Fructose and mannose metabolism & 51 & 16 & 2.1 & 5 & 0.9 & 1 & $\mathrm{n} / \mathrm{a}$ & $\mathrm{n} / \mathrm{a}$ & 0.05 & NS & $\mathrm{n} / \mathrm{a}$ \\
\hline Ubiquitin mediated proteolysis & 4120 & 47 & 6.0 & 1 & $\mathrm{n} / \mathrm{a}$ & $\mathrm{n} / \mathrm{a}$ & 3.2 & 1 & 0.05 & $\mathrm{n} / \mathrm{a}$ & NS \\
\hline Cell cycle-yeast & 4111 & 46 & 5.9 & 1 & $\mathrm{n} / \mathrm{a}$ & $n / a$ & 3.1 & 1 & 0.05 & $\mathrm{n} / \mathrm{a}$ & NS \\
\hline Phagosome & 4145 & 26 & 3.3 & 7 & $\mathrm{n} / \mathrm{a}$ & n/a & 1.4 & 3 & 0.05 & $\mathrm{n} / \mathrm{a}$ & NS \\
\hline NOD-like receptor signaling pathway & 4621 & 3 & 0.4 & 1 & 0.2 & 1 & 0.2 & 1 & NS & 0.05 & NS \\
\hline
\end{tabular}

NS $=$ not significant, $\mathrm{n} / \mathrm{a}=$ no transcripts identified matching this pathway

candidate transcripts, 429 were represented on the second-generation microarray.

Three different strains of E. amylovora (Ea2002a, Ea273a, and Ea4001a) were used to determine the susceptibility of the segregating population. Regression analysis of the data identified a set of 39 transcripts out of the 429 candidates that had some association with fire blight resistance in the breeding population (Table 5). The transcripts included in this set had un-adjusted pvalues of less than 0.05 .

For the transcripts identified as having higher levels of expression in less susceptible trees, 3 had an un-adjusted p-value below 0.05 for two strains, and 36 had an unadjusted p-value below 0.05 for one strain. For those transcripts that had higher expression levels in the more susceptible scion/rootstock combinations, only 3 transcripts had un-adjusted p-values below 0.05 . The transcript list in Table 5 includes 3 transcripts previously shown to be differentially expressed upon E. amylovora infection [11] (Table 3). The functional annotation of these genes is included in Table 2. Those pathways, as determined by the KEGG analysis, that had the highest confidence level for being disproportionately represented include: photosynthesis-antenna proteins (ko00196), protein processing in the endoplasmic reticulum (ko04141), and endocytosis (ko4144).

\section{Gene expression patterns correlating with fire blight susceptibility}

A total of 13 genes with higher transcript levels in more resistant trees were identified as being significantly related to the level of fire blight caused by at least one of the three E. amylovora strains, with the resulting regression models accounting for between 40 and $60 \%$ of the variation in disease severity (Additional File 2, Table S5). Of these, increased transcription of one gene (APPLEOF000020273) was negatively related to levels of fire blight caused by all three strains. Increased levels of transcripts of APPLEOF000027501, APPLE00R00018643 and APPLEOF000019968 were related to lower levels of fire blight caused by at least two of the E. amylovora strains, while increased 
Table 3 Transcripts in common with those found to have differential expression in apple upon E. amylovora infection by Norelli et al., [11]

\begin{tabular}{|c|c|c|c|c|c|}
\hline Seq_ID & GenBank_Accn & $\begin{array}{l}\text { Malus Contig } \\
\text { BLAST Hit }\end{array}$ & Description & evalue & $\begin{array}{l}\text { SSH } \\
\text { Response }^{\S}\end{array}$ \\
\hline APPLEOF000017044/ & EG974017 & MDC011793.214 & plastocyanin-like domain-containing protein & $9 \mathrm{E}-14$ & $\begin{array}{l}\text { early up- } \\
\text { regulated }\end{array}$ \\
\hline \multicolumn{6}{|l|}{ APPLEOFR00078469 } \\
\hline APPLEOF000011437/ & & & fibrillarin 1 (FBR1) (FIB1) (SKIP7) identical to fibrillarin 1 & $1 \mathrm{E}-59$ & \\
\hline APPLEOF000051475/ & EG974020 & MDC019359.48 & Gl:9965653 from [A. thaliana]; C-terminus identical to SKP1 & $3 \mathrm{E}-53$ & $\begin{array}{l}\text { early up- } \\
\text { regulated }\end{array}$ \\
\hline APPLEOF000020924 & & & interacting partner $7 \mathrm{Gl}: 10716959$ from [A. thaliana] & $3 \mathrm{E}-28$ & \\
\hline APPLEOF000022573 & EH009495 & MDC009164.88 & putative cytochrome c oxidase subunit 5c [Helianthus annuus] & $5 \mathrm{E}-14$ & $\begin{array}{l}\text { up- } \\
\text { regulated } 1 \\
\text { hpi }\end{array}$ \\
\hline APPLEOF000017734/ & EH009489 & MDC002049.218 & leucine-rich repeat transmembrane protein kinase, putative & $4 \mathrm{E}-11$ & $\begin{array}{l}\text { up- } \\
\text { regulated } 1 \\
\text { hpi }\end{array}$ \\
\hline APPLEOF000060312 & & & & $9 \mathrm{E}-06$ & \\
\hline APPLEOF000019504 & EH009551 & MDC011946.321 & L-ascorbate peroxidase 1, cytosolic (APX1 & $7 \mathrm{E}-12$ & $\begin{array}{l}\text { up- } \\
\text { regulated } 1 \\
\text { hpi }\end{array}$ \\
\hline APPLEOFR00043470 & $\mathrm{EH} 009570$ & MDC010527.333 & $\begin{array}{l}\text { Encodes a novel component essential for NDH-mediated non- } \\
\text { photochemical reduction of the plastoquinone pool in } \\
\text { chlororespiratory electron transport. }\end{array}$ & & $\begin{array}{l}\text { up- } \\
\text { regulated } 1 \\
\text { hpi }\end{array}$ \\
\hline APPLEOF000017575/ & EH009572 & MDC015841.261 & oxygen-evolving enhancer protein 3, chloroplast, putative & $5 \mathrm{E}-13$ & $\begin{array}{l}\text { up- } \\
\text { regulated } 1 \\
\text { hpi }\end{array}$ \\
\hline APPLEOF000020381 & & & (PSBQ2 & 7E-11 & \\
\hline APPLEOF000015792 & EH009577 & MDC006495.372 & catalase 3 (SEN2) & $3 \mathrm{E}-12$ & $\begin{array}{l}\text { up- } \\
\text { regulated } 1 \\
\text { hpi }\end{array}$ \\
\hline APPLEOF000015821 & & & & $4 \mathrm{E}-16$ & \\
\hline \multirow[t]{2}{*}{ APPLEOF000006776 } & EH009561/ & MDC013772.152 & putative strong similarity to plastidic fructose-bisphosphate) & $3 \mathrm{E}-25$ & $\begin{array}{l}\text { up- } \\
\text { regulated } 1 \\
\text { hpi }\end{array}$ \\
\hline & EH009491 & & aldolase (EC 4.1.2.13) from Nicotiana paniculata (NPALDP1 & & \\
\hline APPLE00R00054041 & EH009563 & MDC008063.227 & similar to putative $60 \mathrm{~S}$ acidic ribosomal protein P0 GB:P50346 & $4 \mathrm{E}-32$ & $\begin{array}{l}\text { up- } \\
\text { regulated } 1 \\
\text { hpi }\end{array}$ \\
\hline APPLEOF000022368 & EH090785 & MDC016063.220 & Glycine-rich RNA-binding protein 7 A. thaliana\} & $2 \mathrm{E}-11$ & $\begin{array}{l}\text { up- } \\
\text { regulated } 12 \\
\text { hpi }\end{array}$ \\
\hline APPLE00R00018459 & EH090787 & MDC002341.180 & 40 S ribosomal protein S27 (ARS27A & $2 \mathrm{E}-17$ & $\begin{array}{l}\text { up- } \\
\text { regulated } 12 \\
\text { hpi }\end{array}$ \\
\hline APPLEOF000016047/ & EH090788 & MDC013560.291 & chlorophyll A-B binding protein 2, chloroplast/LHCII type I & $5 \mathrm{E}-27$ & $\begin{array}{l}\text { up- } \\
\text { regulated } 12 \\
\text { hpi }\end{array}$ \\
\hline APPLEOF000021251 & & & CAB-2/CAB-140 (CAB2B) & & \\
\hline APPLE00R00018530 & EH090762 & MDC009496.462 & putative mRNA binding protein precursor (GI:26453355) & $1 \mathrm{E}-22$ & $\begin{array}{l}\text { up- } \\
\text { regulated } 2 \\
\text { hpi }\end{array}$ \\
\hline APPLEOF000021275 & EH090763 & MDC011225.39 & $\begin{array}{l}\text { dehydrin ERD10 (Low-temperature-induced protein LTI45) [A. } \\
\text { thaliana] SWISS-PROT:P42759 }\end{array}$ & & $\begin{array}{l}\text { up- } \\
\text { regulated } 2 \\
\text { hpi }\end{array}$ \\
\hline APPLEOF000020273 & $\mathrm{EH} 090764$ & MDC007862.188 & $\begin{array}{l}\text { heat shock protein 81-4 (HSP81-4) contains Pfam profiles PF02518, } \\
\text { PF00183: Hsp90 pro }\end{array}$ & $1 \mathrm{E}-22$ & $\begin{array}{l}\text { up- } \\
\text { regulated } 2 \\
\text { hpi }\end{array}$ \\
\hline
\end{tabular}


Table 3 Transcripts in common with those found to have differential expression in apple upon E. amylovora infection by Norelli et al., [11] (Continued)

\begin{tabular}{|c|c|c|c|c|c|}
\hline APPLEOF000017683/ & EG974803 & MDC009596.270 & sugar transporter, putative similar to ERD6 protein $\{$ A. thaliana\} & $8 \mathrm{E}-29$ & $\begin{array}{l}\text { up- } \\
\text { regulated } 48 \\
\text { and } 72 \mathrm{hpi}\end{array}$ \\
\hline APPLEOF000019355 & & & & $1 \mathrm{E}-33$ & 72 hpi \\
\hline APPLEOF000015156 & EG974779 & MDC021689.444 & $\begin{array}{l}\text { contains Pfam profile PF00407: Pathogenesis-related protein Bet v } \\
\text { I family }\end{array}$ & $1 \mathrm{E}-11$ & $\begin{array}{l}\text { up-reg. } 48 \\
\text { and } 72 \text { hpi }\end{array}$ \\
\hline \multicolumn{6}{|l|}{ APPLE0F000018467/ } \\
\hline \multicolumn{6}{|l|}{ APPLEOF000019900/ } \\
\hline APPLEOF000060942/ & EG974812 & MDC007381.261 & cytosolic (GAPC)/NAD-dependent glyceraldehyde-3-phosphate & $1 \mathrm{E}-20$ & $\begin{array}{l}\text { up-reg. } 48 \\
\text { and } 72 \text { hpi }\end{array}$ \\
\hline APPLEOFR00073702/ & & & dehydrogenase & & \\
\hline \multicolumn{6}{|l|}{ APPLEOFR00045573/ } \\
\hline$\underline{\text { APPLEOF000015746 }}$ & EG974761 & MDC017137.174 & $\begin{array}{l}\text { ribulose bisphosphate carboxylase small chain 3B/RuBisCO small } \\
\text { subunit 3B (RBCS-3B) (ATS3B }\end{array}$ & $8 \mathrm{E}-20$ & $\begin{array}{l}\text { up-reg. } 48 \\
\text { and } 72 \text { hpi }\end{array}$ \\
\hline \multirow[t]{2}{*}{ APPLE00R00062179 } & EH034496/ & MDC006746.407 & conserved hypothetical protein [Corynebacterium efficiens YS- & $4 \mathrm{E}-07$ & $\begin{array}{l}\text { early up- } \\
\text { reg., down-, }\end{array}$ \\
\hline & EG974019 & & 314] mitochondrial 265 ribosomal RNA protein & & reg. 2 hpi \\
\hline \multicolumn{6}{|l|}{ APPLE00R00062069/ } \\
\hline APPLEO0R00062142/ & & & & & $\begin{array}{l}\text { early up- } \\
\text { reg., up-reg. }\end{array}$ \\
\hline APPLEOFR00063223/ & EH009493/ & MDC021568.167 & 3'utr of MDP0000053760 Unknown A. thaliana. protein & $3 \mathrm{E}-12$ & $\begin{array}{l}1 \text { hpi, } \\
\text { down-reg. } 2\end{array}$ \\
\hline APPLEOFR00072001/ & EG974018 & & & & hpi, \\
\hline \multicolumn{6}{|l|}{ APPLEOFR00074986 } \\
\hline APPLEOF000019494/ & EH034531/ & MDC008933.302 & jasmonate-zim-domain protein 1 & & $\begin{array}{l}\text { up-reg. } 1 \\
\text { hpi, down- }\end{array}$ \\
\hline APPLEOFR00070531 & EH009567 & & & & reg. 2 hpi \\
\hline APPLEOF000015761/ & EH034470/ & & & $1 \mathrm{E}-20$ & \\
\hline APPLEOF000016441/ & EH034448/ & MDC012615.331 & chlorophyll A-B binding protein 2, chloroplast/LHCII type I & $3 \mathrm{E}-70$ & $\begin{array}{l}\text { up-reg. } 1 \\
\text { hpi, down- }\end{array}$ \\
\hline$\underline{\text { APPLEOF000017178/ }}$ & EH009539/ & & CAB-2/CAB-140 (CAB2B) & $1 \mathrm{E}-20$ & reg. 2 hpi, \\
\hline \multirow[t]{4}{*}{ APPLEOF000016322 } & EH009499 & & & $1 \mathrm{E}-70$ & \\
\hline & EH034678/ & & & & \\
\hline & EH034677/ & & & & \\
\hline & EH034635/ & & & & $\begin{array}{l}\text { up-reg. } 1 \\
\text { hpi, down- }\end{array}$ \\
\hline APPLE00R00015736/ & EH034631/ & MDC017026.232 & ribulose bisphosphate carboxylase small chain 3B/RuBisCO & $4 \mathrm{E}-26$ & $\begin{array}{l}\text { reg. } 1 \text { hpi, } \\
\text { down-reg. }\end{array}$ \\
\hline \multirow[t]{6}{*}{$\underline{\text { APPLEOF000025537 }}$} & EH034620/ & & small subunit 3B (RBCS-3B) (ATS3B) & & $\begin{array}{l}12 \text { hpi, } \\
\text { down-reg. } \\
24\end{array}$ \\
\hline & EH034600/ & & & & $\begin{array}{l}\text { hpi, down- } \\
\text { reg. } 48\end{array}$ \\
\hline & EH034581/ & & & & hpi, \\
\hline & EH034578/ & & & & \\
\hline & EH009517/ & & & & \\
\hline & EH009492 & & & & \\
\hline APPLE00R00061494 & EH034644 & MDC008988.418 & $\begin{array}{l}\text { ribosomal protein L2 family protein similar to ribosomal protein L2 } \\
\text { [Gossypium arboreum] Gl:17644114; contains Pfam profile } \\
\text { PF03947: Ribosomal Proteins L2, C-terminal domain }\end{array}$ & $4 \mathrm{E}-07$ & $\begin{array}{l}\text { down- } \\
\text { regulated } 1 \\
\text { hpi }\end{array}$ \\
\hline APPLEO0R00016015 & EH034651 & MDC013883.400 & $\begin{array}{l}\text { glycosyl hydrolase family } 1 \text { protein contains Pfam PF00232: } \\
\text { domain; TIGRFAM TIGR01233: 6-phospho-beta-galactosidase; } \\
\text { similar to amygdalin hydrolase isoform AH I precursor }\end{array}$ & $1 \mathrm{E}-22$ & $\begin{array}{l}\text { down- } \\
\text { regulated } 1 \\
\text { hpi }\end{array}$ \\
\hline
\end{tabular}


Table 3 Transcripts in common with those found to have differential expression in apple upon E. amylovora infection by Norelli et al., [11] (Continued)

\begin{tabular}{|c|c|c|c|c|c|}
\hline APPLEOF000019334 & $\mathrm{EH} 034681$ & MDC023674.27 & expressed protein & $4 \mathrm{E}-25$ & $\begin{array}{l}\text { down- } \\
\text { regulated } 1 \\
\text { hpi }\end{array}$ \\
\hline \multirow[t]{2}{*}{ APPLEOF000015900 } & EH034690 & MDC013694.297 & $\begin{array}{l}\text { 68414.m02538 plastocyanin similar to plastocyanin Gl:1865683 } \\
\text { from [A. thaliana] }\end{array}$ & $9 \mathrm{E}-11$ & $\begin{array}{l}\text { down- } \\
\text { regulated } 1 \\
\text { hpi }\end{array}$ \\
\hline & EH034668/ & & & & \\
\hline \multirow[t]{2}{*}{ APPLEOFR00069028 } & EH034488/ & MDC019115.109 & piggyBac transposable element derived 5 [Homo sapiens] & $1 \mathrm{E}+00$ & $\begin{array}{l}\text { down-reg. } 1 \\
\text { hpi, }\end{array}$ \\
\hline & $\mathrm{EH} 034454$ & & & & $\begin{array}{l}\text { down-reg. } 2 \\
\text { hpi }\end{array}$ \\
\hline \multirow[t]{2}{*}{ APPLEOF000059582 } & EH034691/ & MDC011711.503 & elongation factor 1-alpha/EF-1-alpha & $1 \mathrm{E}-81$ & $\begin{array}{l}\text { down-reg. } 1 \\
\text { hpi, }\end{array}$ \\
\hline & $\mathrm{EH} 034556$ & & & & $\begin{array}{l}\text { down-reg. } \\
24 \text { hpi }\end{array}$ \\
\hline \multirow[t]{2}{*}{$\underline{\text { APPLEOF000021983 }}$} & EH034459/ & MDC004849.508 & sodium/calcium exchanger family protein/calcium-binding EF & $2 \mathrm{E}-18$ & $\begin{array}{l}\text { down- } \\
\text { regulated } 2 \\
\text { hpi }\end{array}$ \\
\hline & $\mathrm{EH} 034663$ & & hand family protein contains Pfam profiles: PF01699 & & \\
\hline \multirow[t]{2}{*}{ APPLEOF000017271 } & EH034459/ & MDC004849.509 & oxygen-evolving enhancer protein, chloroplast, putative/33 kDa & $3 \mathrm{E}-48$ & $\begin{array}{l}\text { down- } \\
\text { regulated } 2 \\
\text { hpi }\end{array}$ \\
\hline & $\mathrm{EH} 034663$ & & subunit of oxygen evolving system of photosystem II, & & \\
\hline APPLEOF000022030 & $\mathrm{EH} 034485$ & MDC015890.82 & ADP-ribosylation factor, putative similar to DCARF1 & $3 \mathrm{E}-26$ & $\begin{array}{l}\text { down- } \\
\text { regulated } 2 \\
\text { hpi }\end{array}$ \\
\hline$\underline{\text { APPLEOF000018523 }}$ & $\mathrm{EH} 034540$ & MDC015915.252 & $\begin{array}{l}\text { heat shock protein } 70 \text {, putative/HSP70, putative strong similarity to } \\
\text { heat shock protein Gl:425194 [Spinacia oleracea] }\end{array}$ & $8 \mathrm{E}-49$ & $\begin{array}{l}\text { down- } \\
\text { regulated } 2 \\
\text { hpi }\end{array}$ \\
\hline$\underline{\text { APPLEOF000020112 }}$ & $\mathrm{EH} 034525$ & MDC000302.731 & $\begin{array}{l}\text { ribulose bisphosphate carboxylase small chain 3B/RuBisCO small } \\
\text { subunit 3B (RBCS-3B) (ATS3B) }\end{array}$ & 7E-06 & $\begin{array}{l}\text { down- } \\
\text { regulated } 2 \\
\text { hpi }\end{array}$ \\
\hline \multicolumn{6}{|l|}{ APPLEOF000050108/ } \\
\hline APPLEOF000061371/ & $\mathrm{EH} 034439$ & MDC021556.182 & polyubiquitin (UBQ4) identical to Gl:17677 & $1 \mathrm{E}-112$ & $\begin{array}{l}\text { down- } \\
\text { regulated } 2 \\
\text { hpi }\end{array}$ \\
\hline \multicolumn{6}{|l|}{ APPLEOF000022561 } \\
\hline APPLEOF000060823 & $\mathrm{EH} 034517$ & MDC012000.76 & heat shock cognate 70 kDa protein 1 (HSC70-1) (HSP70-1) & & $\begin{array}{l}\text { down- } \\
\text { regulated } 2 \\
\text { hpi }\end{array}$ \\
\hline \multirow[t]{2}{*}{ APPLEOF000017293 } & EH034563/ & MDC021812.77 & peroxidase 42 (PER42) (P42) (PRXR1 & $2 \mathrm{E}-57$ & $\begin{array}{l}\text { down-reg. } 2 \\
\text { hpi, }\end{array}$ \\
\hline & $\mathrm{EH} 034487$ & & & & $\begin{array}{l}\text { down-reg. } \\
24 \text { hpi }\end{array}$ \\
\hline APPLEOF000017691 & $\mathrm{EH} 034538$ & MDC021024.27 & phosphatidylinositol-4-phosphate 5-kinase family protein & $4 \mathrm{E}-51$ & $\begin{array}{l}\text { down-reg. } \\
24 \text { hpi }\end{array}$ \\
\hline APPLEOFR00045757 & $\mathrm{EH} 034536$ & MDC016554.129 & $\begin{array}{l}\text { possible } 5^{\prime} \text { utr for Thiamin diphosphate-binding fold (THDP- } \\
\text { binding) superfamily protein }\end{array}$ & & $\begin{array}{l}\text { down-reg. } \\
24 \text { hpi }\end{array}$ \\
\hline APPLE00R00002434/ & $\mathrm{EH} 034628$ & MDC008650.425 & germin-like protein (GER3) & $1 \mathrm{E}-62$ & $\begin{array}{l}\text { down-reg. } \\
48 \text { hpi }\end{array}$ \\
\hline APPLEOF000049504 & & & & 9E-08 & \\
\hline APPLEOF000018527 & $\mathrm{EH} 034604$ & MDC005688.181 & $\begin{array}{l}\text { oxygen-evolving enhancer protein, chloroplast, putative/33 kDa } \\
\text { subunit of oxygen evolving system of photosystem II }\end{array}$ & & $\begin{array}{l}\text { down-reg. } \\
48 \text { hpi }\end{array}$ \\
\hline$\underline{\text { APPLE00R00058028 }}$ & $\mathrm{EH} 034627$ & MDC010241.225 & $\begin{array}{l}\text { putative/L-iditol 2-dehydrogenase, putative similar to NAD- } \\
\text { dependent sorbitol dehydrogenase from Malus x domestica }\end{array}$ & $9 \mathrm{E}-26$ & $\begin{array}{l}\text { down-reg. } \\
48 \text { hpi }\end{array}$ \\
\hline
\end{tabular}


Table 3 Transcripts in common with those found to have differential expression in apple upon E. amylovora infection by Norelli et al., [11] (Continued)

\begin{tabular}{|c|c|c|c|c|c|}
\hline APPLEOFR00038628 & EH009528 & MDC000300.335 & No Hits Found & & $\begin{array}{l}\text { up- } \\
\text { regulated } 1 \\
\text { hpi }\end{array}$ \\
\hline$\underline{\text { APPLEOF000015847/ }}$ & EH034662 & MDC022487.75 & chlorophyll A-B binding protein/LHCII type I (LHB1B1) & $5 \mathrm{E}-31$ & \\
\hline APPLEOF000016638 & & & & $4 \mathrm{E}-40$ & \\
\hline APPLEOFR00073381 & EH034693 & MDC000997.260 & No Hits Found & & \\
\hline APPLEOF000024130 & EH034466 & MDC004582.94 & $\begin{array}{l}\text { protochlorophyllide reductase A, chloroplast/PCR A/NADPH- } \\
\text { protochlorophyllide oxidoreductase A }\end{array}$ & $5 \mathrm{E}-9$ & \\
\hline APPLEOF000059277 & EG974791 & MDC004462.498 & $\begin{array}{l}\text { 60S ribosomal protein L19 (RPL19C) similar to L19 from several } \\
\text { species }\end{array}$ & $4 \mathrm{E}-41$ & \\
\hline APPLEOFR00073380 & EH034693 & MDC000997.260 & No Hits Found & & \\
\hline APPLEOFR00039729 & EH009538 & MDC005169.268 & No Hits Found & & \\
\hline APPLEOFR00036633 & EH009530 & MDC001354.357 & hypothetical protein [Burkholderia fungorum] & .02 & \\
\hline \multicolumn{6}{|l|}{ Up in sensitive } \\
\hline \multirow[t]{2}{*}{ APPLEOF000061746 } & EG974808/ & MDC022200.129 & $\begin{array}{l}\text { catechol oxidase activity molecular function Catalysis of the } \\
\text { reaction: } 2 \text { catechol + O2 metal ion binding molecular function }\end{array}$ & & $\begin{array}{l}\text { up-reg. } 48 \\
\text { and } 72 \text { hpi }\end{array}$ \\
\hline & EG974767 & & Interacting selectively with any metal ion. predicted with glimmer & & \\
\hline APPLEOF000001556 & EH034619 & MDC011650.665 & expressed protein protein induced upon wounding-A. thaliana & $4 \mathrm{E}-79$ & $\begin{array}{l}\text { down- } \\
\text { regulated } 48 \\
\text { hpi }\end{array}$ \\
\hline
\end{tabular}

$\S$ SSH response corresponds to the change in expression after infection.

Bold text corresponds to genes that are phosphorylated upon infection.

Italicized text corresponds to genes that were also identified as differentially expressed upon infection by Baldo et al., [12].

Underlined text corresponds to genes that were also identified as differentially expressed upon infection by Sarowar et al., [13].

Table 4 Transcripts in common with those found to have differential expression in apple upon E. amylovora infection by Baldo et al., [12]

\begin{tabular}{|c|c|c|c|c|c|}
\hline SEQ_ID & GenBank_Accn & $\begin{array}{l}\text { Malus Contig } \\
\text { BLAST Hit }\end{array}$ & Description & evalue & $\begin{array}{l}\text { cDNA-AFLP } \\
\text { response }^{\S}\end{array}$ \\
\hline APPLEOF000017734/ & EX982051 & MDC002049.218 & leucine-rich repeat transmembrane protein kinase, putative" & $4 \mathrm{E}-11$ & up-regulated 2 \\
\hline APPLEOF000060312 & & & & $9 \mathrm{E}-06$ & hpi in M.26 \\
\hline \multicolumn{6}{|l|}{ APPLE00R00062069/ } \\
\hline \multicolumn{6}{|l|}{ APPLE00R00062142/ } \\
\hline APPLEOFR00063223/ & EX982063 & MDC021568.167 & 235aa long hypothetical protein [Pyrococcus horikoshii] & $3 \mathrm{E}-12$ & up-regulated 2 \\
\hline APPLEOFR00072001/ & & & hypothetical protein [Deinococcus radiodurans] & $5 E-11$ & hpi in M.26 \\
\hline \multicolumn{6}{|l|}{ APPLEOFR00074986 } \\
\hline \multicolumn{6}{|l|}{ APPLE00R00062069/ } \\
\hline \multicolumn{6}{|l|}{ APPLE00R00062142/ } \\
\hline APPLEOFR00063223/ & EX982064 & MDC021568.167 & 235aa long hypothetical protein [Pyrococcus horikoshii] & $3 \mathrm{E}-12$ & down-regulated \\
\hline APPLEOFR00072001/ & & & hypothetical protein [Deinococcus radiodurans] & $5 E-11$ & 2 hpi in M.26 \\
\hline \multicolumn{6}{|l|}{ APPLEOFR00074986 } \\
\hline \multicolumn{6}{|l|}{ APPLE00R00062069/ } \\
\hline \multicolumn{6}{|l|}{ APPLE00R00062142/ } \\
\hline APPLEOFR00063223/ & EX982070 & MDC021568.167 & 235aa long hypothetical protein [Pyrococcus horikoshii] & $3 \mathrm{E}-12$ & up-regulated 2 \\
\hline APPLEOFR00063223/ & & & hypothetical protein [Deinococcus radiodurans] & $5 E-11$ & \& 48 hpi \\
\hline APPLEOFR00072001/ & & & & & in $M .26$ \\
\hline \multicolumn{6}{|l|}{ APPLEOFR00074986 } \\
\hline APPLEOF000062056 & EX982066 & MDC001431.265 & hypothetical protein [Oenothera elata subsp. hookeri] & $9 \mathrm{E}-18$ & $\begin{array}{c}\text { up-regulated } 2 \\
\text { hpi in G-41 }\end{array}$ \\
\hline APPLEOFR00045573/ & EY437146 & MDC005648.389 & & & up-regulated 48 \\
\hline APPLEOFR00073702 & & & & & hpi in G-41 \\
\hline
\end{tabular}


Table 4 Transcripts in common with those found to have differential expression in apple upon E. amylovora infection by Baldo et al., [12] (Continued)

\begin{tabular}{|c|c|c|c|c|c|}
\hline APPLEOF000020631/ & EX982080 & MDC005535.336 & $\begin{array}{l}\text { invertase/pectin methylesterase inhibitor family protein similar } \\
\text { to pectinesterase from Arabidosis thaliana }\end{array}$ & $2 \mathrm{E}-19$ & $\begin{array}{l}\text { up-regulated } 48 \\
\text { hpi in G-41 }\end{array}$ \\
\hline APPLEOF000016328/ & & & plasma membrane intrinsic protein, putative very strong & $7 \mathrm{E}-57$ & \\
\hline APPLEOFR00076854/ & EX982085 & MDC003306.225 & similarity to plasma membrane intrinsic protein (SIMIP) & & up-regulated 48 \\
\hline APPLEOFR00076855 & & & [Arabidopsis thaliana] Gl:2306917" & & hpi in G-41 \\
\hline APPLE00R00015876/ & & & & $3 \mathrm{E}-19$ & \\
\hline APPLEOF000019554/ & & & & $4 \mathrm{E}-11$ & \\
\hline APPLEOF000021355/ & EX982096 & MDC012593.380 & chlorophyll A-B binding protein (LHCB2:4) nearly & $7 \mathrm{E}-16$ & up-regulated 48 \\
\hline APPLEOF000024114/ & & & identical to Lhcb2 protein [Arabidopsis thaliana] & $5 \mathrm{E}-06$ & hpi in G-41 \\
\hline APPLEOFR00036952/ & & & Gl:4741950 & & \\
\hline \multicolumn{6}{|l|}{ APPLEOFR00037537 } \\
\hline APPLEOF000062056 & EX982108 & MDC001431.265 & $\begin{array}{c}\text { hypothetical protein [Oenothera elata subsp. hookeri] 3' UTR } \\
\text { of MDP499035 }\end{array}$ & $9 \mathrm{E}-18$ & $\begin{array}{l}\text { down-regulated } \\
48 \text { hpi in G-41 }\end{array}$ \\
\hline
\end{tabular}

$\S$ CDNA-AFLP response corresponds to the change in expression after infection

Bold text corresponds to genes that are phosphorylated upon infection

Italicized text corresponds to genes that were also identified as differentially expressed upon infection by Norelli et al., [11]

Underlined text corresponds to genes that were also identified as differentially expressed upon infection by Sarowar et al., [13].

Table 5 Candidate transcripts whose expression levels correlated with fire blight resistance in a population of trees segregating for fire blight susceptibility (regression analysis).

\begin{tabular}{|c|c|c|c|c|c|c|}
\hline & E. amy & lovora s & strain & & & \\
\hline Seq_ID & E2002a & Ea273 & $4001 a$ & hit & Description & evalue \\
\hline APPLEOF000021750 & & $x$ & $x$ & At3g54020 & inositol phosphorylceramide synthase 2 - & $3 \mathrm{E}-19$ \\
\hline APPLEOF000017942 & & $x$ & $x$ & At5g17420 & cellulose synthase, catalytic subunit (IRX3) identical to gi:5230423 & $5 \mathrm{E}-08$ \\
\hline APPLE00R00017800 & $x$ & & $X$ & At5g02570 & histone $\mathrm{H} 2 \mathrm{~B}$, putative similar to histone $\mathrm{H} 2 \mathrm{~B}-2$ Lycopersicon esculentum & $2 \mathrm{E}-24$ \\
\hline$\underline{\text { APPLEOF000016970 }}$ & $X$ & & & At3g01090 & Snf1-related protein kinase (KIN10) (SKIN10) & $2 \mathrm{E}-14$ \\
\hline APPLEOF000020273* & $x$ & & & At5g56000 & heat shock protein 81-4 (HSP81-4) & \\
\hline APPLEOFR00077763 & $X$ & & & No Hits Found & & $1 \mathrm{E}-34$ \\
\hline APPLEOF000025563 & $X$ & & & At3g47520 & $\begin{array}{c}\text { malate dehydrogenase }[\mathrm{NAD}] \text {, chloroplast }(\mathrm{MDH}) \text { identical to chloroplast } \\
\text { NAD-malate dehydrogenase }[\mathrm{A} \text {. thaliana] Gl:3256066 }\end{array}$ & $9 \mathrm{E}-30$ \\
\hline APPLEOFR00039135 & $x$ & & & No Hits Found & & \\
\hline APPLEOF000018055 & & $x$ & & At3g22550 & similar to senescence-associated protein SAG102 & $4 \mathrm{E}-41$ \\
\hline APPLEOFR00077391 & & $x$ & & No Hits Found & & $1 \mathrm{E}+00$ \\
\hline APPLEOF000059277 & & $x$ & & At4g02230 & 605 ribosomal protein L19 & \\
\hline APPLEOFR00069907 & & $X$ & & No Hits Found & & $2 \mathrm{E}-18$ \\
\hline APPLEOF000018558 & & $x$ & & At3g47470 & chlorophyll A-B binding protein 4, LHCl type III CAB-4 (CAB4) & $1 \mathrm{E}-22$ \\
\hline APPLEOFR00078469 & & $x$ & & No Hits Found & & \\
\hline APPLEOFR00072723 & & $x$ & & $\begin{array}{l}\text { gb|AAD45359| } \\
\text { AF161252_1 }\end{array}$ & cycloidea-like protein [Linaria vulgaris] & $2 \mathrm{E}-06$ \\
\hline APPLEOFR00048629 & & $X$ & & $\begin{array}{c}\text { emb| } \\
\text { CAG59326\| }\end{array}$ & $\begin{array}{l}\text { unnamed protein product [Candida glabrata CBS138] ref|XP_4463991| } \\
\text { unnamed protein product [Candida glabrata] }\end{array}$ & 2.E-02 \\
\hline APPLEOFR00038610 & & $x$ & & No Hits Found & & \\
\hline APPLE00R00062246 & & $x$ & & $\mathrm{dbj}|\mathrm{BAB} 1270|$ & P0671B1122 [Oryza sativa (japonica cultivar-group)] & 2.E-06 \\
\hline APPLEOF000021761 & & $x$ & & At1g72370 & $\begin{array}{l}405 \text { ribosomal protein SA (RPSaA) identical to laminin receptor-like protein } \\
\text { GB:U01955 [A thaliana] }\end{array}$ & 9.E-20 \\
\hline APPLEOFR00036516 & & & $X$ & gb|EAA23003| & Ribosomal protein L31e, putative [Plasmodium yoelii yoelii] & $2 \mathrm{E}-06$ \\
\hline APPLEOFR00076821 & & & $X$ & No Hits Found & & \\
\hline APPLEOFR00076762 & & & $x$ & No Hits Found & & \\
\hline APPLEOF000016441* & & & $x$ & At1g29930 & chlorophyll A-B binding protein 2, LHCII type I CAB-2/CAB-140 & 3.E-70 \\
\hline
\end{tabular}


Table 5 Candidate transcripts whose expression levels correlated with fire blight resistance in a population of trees segregating for fire blight susceptibility (regression analysis). (Continued)

\begin{tabular}{|c|c|c|c|c|c|c|}
\hline APPLEOF000019498 & & & $x$ & At2g42210 & $\begin{array}{l}\text { mitochondrial import inner membrane translocase subunit Tim17/Tim22/ } \\
\qquad \text { Tim23 family protein }\end{array}$ & $8 \mathrm{E}-07$ \\
\hline APPLEOF000018523* & & & $x$ & At3g12580 & heat shock protein 70, putative/HSP70, putative & $8 \mathrm{E}-49$ \\
\hline APPLE00R00018643 & & & $x$ & At3g27690 & chlorophyll A-B binding protein (LHCB2:4) & $4 \mathrm{E}-22$ \\
\hline APPLEOF000020073 & & & $x$ & At2g34690 & expressed protein & $3 \mathrm{E}-14$ \\
\hline$\underline{\text { APPLEOF000021409 }}$ & & & $x$ & At3g05890 & $\begin{array}{l}\text { hydrophobic protein }(\mathrm{RCI} 2 \mathrm{~B}) / \text { low temperature and salt responsive protein } \\
\qquad(\mathrm{LTI} 6 \mathrm{~B})\end{array}$ & $5 E-10$ \\
\hline APPLEOFR00037149 & & & $x$ & No Hits Found & & \\
\hline APPLEOFR00080491 & & & $X$ & $\begin{array}{l}\text { gb|AAK07949| } \\
\text { AF318573_29 }\end{array}$ & unknown [Bovine herpesvirus 4] & $1 \mathrm{E}+00$ \\
\hline APPLEOF000025192 & & & $x$ & At3g56900 & aladin-related/adracalin-related weak similarity to SP|Q9NRG9 & $3 \mathrm{E}-16$ \\
\hline APPLEOF000060354 & & & $X$ & At5g02120 & $68418 m 00133$ thylakoid membrane one helix protein (OHP) & $1 \mathrm{E}+00$ \\
\hline APPLEOF000001282 & & & $x$ & At4g38920 & vacuolar ATP synthase $16 \mathrm{kDa}$ proteolipid subunit 3/N-ATPase & 1.E-34 \\
\hline APPLEOF000058071 & & & $x$ & At1g75780 & tubulin beta-1 chain (TUB1) nearly identical to SP|P12411 & $2 \mathrm{E}-02$ \\
\hline APPLEOF000020583 & & & $x$ & At2g34250 & $\begin{array}{l}\text { protein transport protein sec61, putative similar to PfSec61 [Plasmodium } \\
\text { falciparum] Gl:3057044 }\end{array}$ & $6 \mathrm{E}-34$ \\
\hline APPLEOF000019736 & & & $x$ & At5g39740 & $60 S$ ribosomal protein $L 5$ (RPL5B) ribosomal protein $L 5$, rice & $2 \mathrm{E}-02$ \\
\hline APPLEOFR00045816 & & & $x$ & No Hits Found & & \\
\hline APPLEOFR00036516 & & & $x$ & gb|EAA23003| & Ribosomal protein L31e, putative [Plasmodium yoelii yoelii] & $1 \mathrm{E}-16$ \\
\hline APPLEOF000018069 & & & $x$ & At5g09810 & $\begin{array}{c}\text { actin } 7 \text { (ACT7)/actin } 2 \text { identical to SP|P53492 Actin } 7 \text { (Actin-2) \{Arabidopsis } \\
\text { thaliana\} }\end{array}$ & $4 \mathrm{E}-72$ \\
\hline APPLEOF000026657 $^{\#}$ & & $x$ & & At1g04540 & $\begin{array}{c}\text { C2 domain-containing protein low similarity to cold-regulated gene SRC2 } \\
\text { [Glycine max] }\end{array}$ & $3 \mathrm{E}-11$ \\
\hline APPLEOFR00032503" & & $x$ & & ref|XP_032996| & similar to KIAA0819 protein [Homo sapiens] & $3 \mathrm{E}-01$ \\
\hline APPLEOF000061746" & $X$ & & & $\begin{array}{l}\text { sp|P43309| } \\
\text { PPO_MALDO }\end{array}$ & Polyphenol oxidase, chloroplast precursor (PPO) (Catechol oxidase) & $\mathrm{OE}+00$ \\
\hline
\end{tabular}

$\mathrm{X}=$ an un-adjusted $\mathrm{p}$ value of less than 0.05 for the analysis

* Transcripts also found in Table 3

\# Transcripts less abundant in plants with low susceptibility to fire blight

Underlined text corresponds to genes that were also identified as differentially expressed upon infection by Sarowar et al., [13].

transcript levels of APPLE0F000019334, APPLE0F0 00018558, APPLEOF000020583 and APPLEOF0000 23953 were noted in tissues with higher levels of disease for at least two of the strains (Additional File 2, Table S5).

The models relating the expression of genes with higher levels of expression in more susceptible trees to levels of fire blight were much weaker, only accounting for between 29 and $32 \%$ of disease severity $(0.031 \leq P \leq$ 0.009; Additional File 2, Table S6). In all, lower expression levels of eight of the genes were related to levels of fire blight for at least one of the E. amylovora strains, with APPLE0FR00081295, APPLE0FR00067567 and APPLE0F000016771 being related with higher levels of fire blight caused by Ea 273 (Additional File 2, Table S6). Only the lower transcript levels of APPLEOF000026657 were related to lower levels of fire blight for all three $E$. amylovora strains, while lower transcript levels of APPLEOFR00066754 and APPLEOFR00063520 were associated with lower levels of disease caused by Ea273 and Ea4001a, respectively (Additional File 2, Table S6).

\section{Discussion}

In this study, we found that rootstock genotype influenced 'Gala' scion fire blight susceptibility in grafted apple trees. This indicates that at least some level of resistance possessed by the rootstock can be conferred upon the scion variety that is grafted to it. These phenotypic differences in scion fire blight susceptibility were associated with reproducible patterns of gene expression in uninfected trees. Most of the transcripts identified in this study had higher levels of expression in the least susceptible trees. The expression levels of some of these genes may play a role in determining the susceptibility status of apple trees to E. amylovora prior to infection. Some of the identified genes may also play a role in fire blight disease resistance after infection has begun. It is also possible that some of the genes identified in the study affect the suitability of the host environment for the bacterium, rather than being involved in defense directly.

Tree breeding is a slow and costly process, particularly due to long juvenile periods. The screening of seedlings for the expression of a suite of genes correlated with a 
given trait could provide a valuable short-cut to reduce breeding time. The suite of genes identified in the present study might be useful as predictors of the fire blight resistance status of apple trees and seedlings. Seedlings could be selected based on gene expression patterns associated with favorable traits. This approach is not novel; the use of expression-based markers has proven to be effective in the screening of human breast cancers in order to predict the aggressiveness of the tumor [28]. Some of the genes identified in this study might also be suitable targets for direct manipulation for improvement of apple tree fire blight resistance and for the development of sequence-based molecular breeding markers.

\section{Pathways and processes}

Three transcripts on the array corresponding to genes in the phenylpropanoid pathway were on our preliminary list of rootstock-regulated candidates, including two for chalcone synthase (APPLEOF000017774, APPLEOF0000 178640) and a chalcone isomerase (APPLEOF000056938) (Additional File 1, Table S2). However, these genes do not appear on any of our subsequent lists. Nevertheless, the expression pattern of the genes in the phenylpropanoid pathway as a whole (Figure 2) is consistent with the proposed role of this pathway in the response to E. amylovora infection $[14,15]$. This suggests that the expression of the phenylpropanoid pathway as a whole might be a good predictor of fire blight resistance.

Sorbitol dehydrogenase (SDH) (APPLEOF000058028, APPLE0F000007408, APPLE0F000017030), was found to be expressed at higher levels in the trees that were least susceptible to fire blight (Table 3 and Additional File 1, Table S4). Sorbitol is a major form of translocated sugar in apples [29]. SDH converts sorbitol to fructose in sink tissues [30]. For E. amylovora, sorbitol is an important factor in determining host specificity [31]. It may be that higher SDH levels reduce the availability of sorbitol to E. amylovora. However it has also been shown that high sorbitol levels can inhibit the development of disease symptoms [32]. Our analysis of the recently released apple genome suggests that there may be up to 28 genes encoding SDH enzymes, as opposed to a single copy of SDH in Arabidopsis (AT5G51970). This complexity points to the importance of SDH to apple physiology.

Not surprisingly, there was a GO annotation enrichment among the genes having higher expression in the least susceptible trees (Table 1), with genes predicted to be involved in responses to stress and biotic and abiotic stimuli being disproportionately represented relative to the known apple transcriptome as a whole. Upon further analysis of these transcripts (Table 2), more transcripts than expected, relative to the proportion among all of the transcripts represented on the array, were identified in the secretory pathway, including several heat shock proteins (APPLE0F000018523, APPLE0F000020273, APPLE0F000060823), suggesting that protein processing in the endoplasmic reticulum may be more active in the trees least susceptible to fire blight. Heat shock proteins are important for protein processing in the endoplasmic reticulum and have also been shown to play critical roles in signal transduction in defense responses in tobacco [33]. Additionally, higher levels of the transcripts encoding a predicted calnexin (APPLEOF000027501) and a Sec61 homolog (APPLE0F000020583) were associated with reduced fire blight susceptibility by stepwise multiple regression analysis. Both of these proteins have functional annotations indicating involvement in protein processing in the endoplasmic reticulum. Consistent with these findings, it has been shown that the entire secretory pathway is up-regulated during systemic acquired resistance (SAR) [34] as well as during the $\mathrm{N}$-mediated viral defense response in tobacco [35].

Similarly, from the same data set, a greater than expected number of genes involved in both the endocytosis and peroxisomal pathways were identified, suggesting that these processes may be more active in the least susceptible trees. Intriguingly, endocytosis processes are involved in plant recognition of pathogen-associated molecular patterns (PAMPs) [36]. For example, the bacterial flagellin protein FLG22 is recognized in plants by the FLS2 receptor kinase [37], which leads to endocytosis of the FLS2 receptor and its subsequent degradation by the proteosome [38]. Higher levels of a transcript encoding a predicted fatty acyl CoA ligase (APPLE0F000019968) were associated with reduced fire blight susceptibility by the stepwise multiple regression analysis. The protein encoded by this gene has a functional annotation indicating involvement in endocytosis and fatty acid metabolism. We also identified a transcript encoding a putative phosphatidylinositol-4-phosphate 5-kinase (PIP5K) (APPLE0F000 017691) that had higher expression levels in the least susceptible trees. The product of PIP5K, phosphoinositol 4,5-bisphosphate (PI(4,5)P2), is a key regulator of clathrinmediated endocytosis [39].

\section{Additional candidate genes of particular interest}

A major objective of this study was to identify candidate genes in apple that are potentially involved in determining fire blight resistance prior to an infection event. Interestingly, quite a few of the candidate genes identified in our study had previous links to disease resistance processes, including differential expression upon E. amylovora infection in apple [11-13]. This includes several heat shock proteins, a leucine-rich repeat transmembrane kinase, and sorbitol dehydrogenase. Strikingly, over half of the transcripts that we identified as being expressed at higher levels in less susceptible trees are down-regulated during 
E. amylovora infection [11-13]. It is possible that the expression of these genes is down-regulated by the pathogen to promote disease. Additionally, eight of the genes in both Tables 3 have also been shown to be phosphorylated upon infection [40], which offers another level of regulation in addition to changes in transcript abundance.

Only one gene was found in common between our data set and those of Norelli et al. [11], Baldo et al. [12], and Sarowar et al [13]. This gene had higher steady-state expression levels in resistant trees and was up-regulated in all three pathogen induction studies. The Arabidopsis homolog of APPLEOF000017734/APPLEOF000060312 (AT2G31880 or SOBIR1) (Tables 3 and 4, Additional File 1 , Table S4) encodes a putative leucine rich repeat transmembrane protein that is expressed in response to Pseudomonas syringae infection in Arabidopsis. Overexpression of SOBIR1 in Arabidopsis caused a constitutive upregulation of $P R-1$ and $P R-2$, and the plants showed enhanced resistance to $P$. syringae DC3000, suggesting that elevated levels of SOBIR1 lead to a constitutive activation of disease-resistance responses [41]. SOBIR1 overexpression also resulted in the activation of cell death. It has been proposed that SOBIR1 may play a role in the regulation of the golgi apparatus, particularly during periods of cellular stress [42].

We also identified a transcript encoding a putative cell death regulator, inositolphosphorylceramide synthase (APPLE0F000021750, Additional File 1, Table S4), that had higher expression levels in the least susceptible trees. Inositol can be modified by inositolphosphorylceramide synthase to produce inositolphosphorylceramide. Inositolphosphorylceramide has been shown to be involved in the regulation of programmed cell death during the plant defense response [43].

Jasmonic acid has been shown to play an important role in the response to pathogens, in a pathway parallel to that of salicylic acid $[44,45]$. In particular, ethylene and jasmonate have been shown to play an important role in defense against necrotrophic pathogens like E. amylovora [46]. We also identified homologs of the $J A Z 1$ gene in Arabidopsis (APPLE0F000019494/APPLE0F000070531, Table 3, Additional File 1, Table S4) that had greater expression in the least sensitive trees. The JAZ1 protein of Arabidopsis is part of the COI1/JAZ jasmonate receptor complex [47].

\section{Conclusions}

The influence of rootstocks on the fire blight susceptibility and gene expression of the scion has allowed us to identify genes potentially associated with this phenotypic trait. The identification of these genes will contribute to the understanding of host-pathogen interactions as well as provide plant breeders with valuable new markers for improved disease resistance breeding. This study illustrates the utility of our rootstock-regulated gene expression data sets for candidate trait-associated gene data mining.

\section{Additional material}

\begin{abstract}
Additional file 1: Tables S1-S4. Table S1. Expression patterns of putative phenylpropanoid genes from Malus $x$ domestica. Table S2. Candidate fire blight resistance transcripts with higher expression in 'Gala' scion/rootstock combinations with lower susceptibility to E. amylovora. Table S3. Candidate fire blight resistance transcripts with higher expression in 'Gala' scion/rootstock combinations with higher susceptibility to E. amylovora. Table S4. Transcripts in common with those known to have differential expression in apple flowers upon $E$. amylovora infection [13] (Sarowar et al. 2011).
\end{abstract}

Additional file 2: Tables S5-S6. Table S5. Stepwise multiple regression analysis parameter estimates and associated statistics for transcripts with higher expression in less susceptible trees. Table S6. Stepwise multiple regression analysis parameter estimates and associated statistics for transcripts with higher expression in more susceptible trees.

\section{Acknowledgements}

This project was funded by NSF Plant Genome Research Program Grant No. 04-20394 to TWM, SNM, JWT and RMC. We thank Candace L. Price for performing sample labeling and hybridization of our second-generation DNA microarrays.

\section{Author details}

'Department of Plant Pathology, The Pennsylvania State University, University Park, PA 16802, USA. ${ }^{2}$ The Pennsylvania State University Fruit Research and Extension Center, Biglerville, PA 17307, USA. ${ }^{3}$ USDA/ARS, Plant Genetics Research Unit, Geneva, NY 14456, USA. ${ }^{4}$ Institute of Molecular Biology and Biotechnology, Faculty of Biology, Adam Mickiewicz University, Poznan, Poland. ${ }^{5}$ Department of Statistics, The Pennsylvania State University, University Park, PA 16802, USA. ${ }^{6}$ Huck Institutes of the Life Sciences, The Pennsylvania State University, University Park, PA 16802, USA. ${ }^{7}$ Department of Horticulture, The Pennsylvania State University, University Park, PA 16802, USA.

\section{Authors' contributions}

TWM conceived the study and participated in its design and coordination. PJJ performed plant material preparation and mRNA extraction for microarray hybridizations. PJJ and NA carried out the computational analysis of the microarray data. NH and JWT conducted the fire blight susceptibility field study in Biglerville, PA. GF provided the tree samples and fire blight data from Geneva, NY. IM developed the contig sequences used for the microarray. CP and SNM assisted in the experimental design. CP performed the second-generation microarray hybridizations. RMC contributed to the experimental design, selection of rootstocks and general culture of trees in the field. HKN performed the multiple regression analysis of the gene expression data. PJJ and TWM analyzed the computational results and drafted the manuscript. All authors commented on the manuscript and approved the final version.

\section{Competing interests}

The authors declare that they have no competing interests.

Received: 8 July 2011 Accepted: 9 January 2012

Published: 9 January 2012

\section{References}

1. Burill TJ: Anthrax of fruit trees; or the so-called fire blight of pear, and twig blight of apple trees. Am Ass Adv Sci Proc 1880, 29:583-597.

2. McManus PS, Stockwell VO, Sundin GW, Jones AL: Antibiotic use in plant agriculture. Annual Review of Phytopathology 2002, 40:443-465.

3. Agrios GN: Plant Pathology. 4 edition. California: Academic Press; 1997. 
4. Autio WR, Southwick FW: The effects of rootstock and root-interstem combination on the growth, productivity, and anchorage of a spur and standard strain of delicious apple tree. Fruit Varieties Journal 1986, 40(4):128-133.

5. Wilcox WF: Fire blight fact sheet. 1994 [http://www.nysipm.cornell.edu/ factsheets/treefruit/diseases/fb/fb.pdf].

6. Carlson RF: Rootstocks in relation to apple cultivars. In North American Apples: Varieties, Rootstocks, Outlook. Edited by: Carlson RF, Degman ES, French AP, Larsen RP, Maas V, Mowry JB, Rollins HA, Upshall WH, Wilcox E. East Lansing, MI: Michigan State University Press; 1970:153-180.

7. Cline JA, Hunter DM, Bonn WG, Bijl M: Resistance of the Vineland series of apple rootstocks to fire blight caused by Erwinia amylovora. Journal American Pomological Society 2001, 55(4):218-221.

8. Maxson-Stein K, He SY, Hammerschmidt R, Jones AL: Effect of treating apple trees with acibenzolar-S-methyl on fire blight and expression of pathogenesis-related protein genes. Plant Disease 2002, 86(7):785-790.

9. Bonasera JM, Kim JF, Beer SV: PR genes of apple: identification and expression in response to elicitors and inoculation with Erwinia amylovora. BMC Plant Biology 2006, 6:23.

10. Malnoy M, Jin Q, Borejsza-Wysocka EE, He SY, Aldwinckle HS: Overexpression of the apple MpNPR1 gene confers increased disease resistance in Malus x domestica. Molecular Plant-Microbe Interactions 2007, 20(12):1568-1580.

11. Norelli JL, Farrell RE, Bassett CL, Baldo AM, Lalli DA, Aldwinckle HS, Wisniewski ME: Rapid transcriptional response of apple to fire blight disease revealed by CDNA suppression subtractive hybridization analysis. Tree Genetics \& Genomes 2009, 5(1):27-40.

12. Baldo A, Norelli JL, Farrell RE Jr, Bassett CL, Aldwinckle HS, Malnoy M: Identification of genes differentially expressed during interaction of resistant and susceptible apple cultivars (Malus $\mathrm{x}$ domestica) with Erwinia amylovora. BMC Plant Biology 2010, 10.

13. Sarowar S, Zhao Y, Soria-Guerra RE, Ali S, Zheng D, Wang D, Korban SS: Expression profiles of differentially regulated genes during the early stages of apple flower infection with Erwinia amylovora. J Exp Bot 2011.

14. Venisse JS, Malnoy M, Faize M, Paulin JP, Brisset MN: Modulation of defense responses of Malus spp. during compatible and incompatible interactions with Erwinia amylovora. Molecular Plant-Microbe Interactions 2002, 15(12):1204-1212.

15. Milcevicova R, Gosch C, Halbwirth H, Stich K, Hanke MV, Peil A, Flachowsky H, Rozhon W, Jonak C, Oufir M, et al: Erwinia amylovorainduced defense mechanisms of two apple species that differ in susceptibility to fire blight. Plant Science 2010, 179(1-2):60-67.

16. Frick S, Kutchan TM: Molecular cloning and functional expression of $\mathrm{O}-$ methyltransferases common to isoquinoline alkaloid and phenylpropanoid biosynthesis. Plant Journal 1999, 17(4):329-339.

17. Whetten R, Sederoff R: Lignin biosynthesis. Plant Cell 1995, 7(7):1001-1013.

18. Jensen PJ, Makalowska I, Altman N, Fazio G, Praul C, Maximova SN, Crassweller RM, Travis JW, McNellis TW: Rootstock-regulated gene expression patterns in apple tree scions. Tree Genetics \& Genomes 2010, 6(1):57-72.

19. Fazio $G$, Wan $Y$, Russo NL, Aldwinckle HS: Investigation on the inheritance of strain specific resistance to Erwinia amylovora in an apple rootstock segregating population. In Proceedings of the Sixth International Workshop on Fire Blight: 12-17 Auqust 2007. Edited by: Johnson KB, Stockwell VO Portland, OR: ISHS Acta Horticulturae; 2008:331-336.

20. Gene Expression Omnibus (GEO) dataset website:[http://www.ncbi.nlm.nih. gov/geo/query/acc.cgi?acc=GPL3715].

21. Irizarry RA, Hoobs B, Collin F, Beazer-Barclay YD, Antonellis KJ, Scherf U, Speed TP: Exploration, normalization, and summaries of high density oligonucleotide array probe level data. Biostat 2003, 4:249-264.

22. Bioconductor:[http://www.bioconductor.org/].

23. Afifi AA, Clark V, May S: Computer-Aided Multivariate Analysis Fourth Edition Boca Raton, FL: Chapman \& Hall/CRC; 2004.

24. Lee SA, Ngugi HK, Halbrendt NO, O'Keefe G, Lehman B, Travis JW, Sinn JP, McNellis TW: Virulence characteristics accounting for fire blight disease severity in apple trees and seedlings. Phytopathology 2010, 100(6):539-550.

25. AraCyc Pathways:[http://www.arabidopsis.org/biocyc/index.jsp].
26. KEGG Automatic Annotation Server:[http://www.genome.jp/tools/kaas/].

27. Velasco R, Zharkikh A, Affourtit J, Dhingra A, Cestaro A, Kalyanaraman A, Fontana P, Bhatnagar SK, Troggio M, Pruss D, et al: The genome of the domesticated apple (Malus x domestica Borkh.). Nature Genetics 2010, 42(10):833-839.

28. van't Veer L, Dai HY, van de Vijver MJ, He YDD, Hart AAM, Mao M, Peterse HL, van der Kooy K, Marton MJ, Witteveen AT, et al: Gene expression profiling predicts clinical outcome of breast cancer. Nature 2002, 415(6871):530-536

29. Bieleski RL: Accumulation and translocation of sorbitol in apple phloem. Australian Journal of Biological Sciences 1969, 22(3):611-620.

30. Negm FB, Loescher WH: Detection and characterization of sorbitol dehydrogenase for apple callus-tissue. Plant Physiology 1979, 64(1):69-73.

31. Aldridge P, Metzger M, Geider K: Genetics of sorbitol metabolism in Erwinia amylovora and its influence on bacterial virulence. Molecular \& General Genetics 1997, 256(6):611-619.

32. Suleman P, Steiner PW: Relationship between sorbitol and solute potential in apple shoot relative to fire blight symptom development after infection by Erwinia amylovora. Phytopathology 1994, 84(10):1244-1250.

33. Kanzaki H, Saitoh H, Ito A, Fujisawa S, Kamoun S, Katou S, Yoshioka H, Terauchi R: Cytosolic HSP90 and HSP70 are essential components of INF1-mediated hypersensitive response and non-host resistance to Pseudomonas cichorii in Nicotiana benthamiana. Molecular Plant Pathology 2003, 4(5):383-391

34. Wang $D$, Weaver ND, Kesarwani M, Dong XN: Induction of protein secretory pathway is required for systemic acquired resistance. Science 2005, 308(5724):1036-1040

35. Caplan JL, Zhu XH, Mamillapalli P, Marathe R, Anandalakshmi R, DineshKumar SP: Induced ER chaperones regulate a receptor-like kinase to mediate antiviral innate immune response, in plants. Cell Host \& Microbe 2009, 6(5):457-469

36. Gordon S: Pattern recognition receptors: Doubling up for the innate immune response. Cell 2002, 111(7):927-930.

37. Gomez-Gomez L, Boller T: FLS2: An LRR receptor-like kinase involved in the perception of the bacterial elicitor flagellin in Arabidopsis. Molecular Cell 2000, 5(6):1003-1011

38. Robatzek S, Chinchilla D, Boller T: Ligand-induced endocytosis of the pattern recognition receptor FLS2 in Arabidopsis. Genes \& Development 2006, 20(5):537-542

39. Simonsen A, Wurmser AE, Emr SD, Stenmark $H$ : The role of phosphoinositides in membrane transport. Current Opinion in Cell Biology 2001, 13(4):485-492.

40. Jones AME, Bennett MH, Mansfield JW, Grant M: Analysis of the defence phosphoproteome of Arabidopsis thaliana using differential mass tagging. Proteomics 2006, 6(14):4155-4165

41. Gao MH, Wang X, Wang DM, Xu F, Ding XJ, Zhang ZB, Bi DL, Cheng YT, Chen S, Li X, et al: Regulation of cell death and innate immunity by two receptor-like kinases in Arabidopsis. Cell Host \& Microbe 2009, 6(1):34-44.

42. Leslie ME, Lewis MW, Youn JY, Daniels MJ, Liljegren SJ: The EVERSHED receptor-like kinase modulates floral organ shedding in Arabidopsis. Development 2010, 137(3):467-476.

43. Wang WM, Yang $X H$, Tangchaiburana $S$, Ndeh R, Markham JE, Tsegaye $Y$, Dunn TM, Wang GL, Bellizzi M, Parsons JF, et al: An inositolphosphorylceramide synthase is involved in regulation of plant programmed cell death associated with defense in Arabidopsis. Plant Cell 2008, 20(11):3163-3179.

44. Thomma B, Eggermont K, Penninckx I, Mauch-Mani B, Vogelsang R, Cammue BPA, Broekaert WF: Separate jasmonate-dependent and salicylate-dependent defense-response pathways in Arabidopsis are essential for resistance to distinct microbial pathogens. Proceedings of the National Academy of Sciences of the United States of America 1998, 95(25):15107-15111.

45. Vijayan P, Shockey J, Levesque CA, Cook RJ, Browse J: A role for jasmonate in pathogen defense of Arabidopsis. Proceedings of the National Academy of Sciences of the United States of America 1998, 95(12):7209-7214. 
46. Glazebrook J: Contrasting mechanisms of defense against biotrophic and necrotrophic pathogens. Annual Review of Phytopathology 2005,

43:205-227.

47. Sheard LB, Tan X, Mao HB, Withers J, Ben-Nissan G, Hinds TR, Kobayashi Y, Hsu FF, Sharon M, Browse J, et al: Jasmonate perception by inositolphosphate-potentiated COI1-JAZ co-receptor. Nature 2010, 468(7322):400-405.

doi:10.1186/1471-2164-13-9

Cite this article as: Jensen et al:: Rootstock-regulated gene expression patterns associated with fire blight resistance in apple. BMC Genomics 2012 13:9.

Submit your next manuscript to BioMed Central and take full advantage of:

- Convenient online submission

- Thorough peer review

- No space constraints or color figure charges

- Immediate publication on acceptance

- Inclusion in PubMed, CAS, Scopus and Google Scholar

- Research which is freely available for redistribution 